\title{
THE EFFECT OF MORTGAGE ORIGINATION FEES ON THE HOUSING PRICE DYNAMICS
}

\author{
Ashot Tsharakyan
}
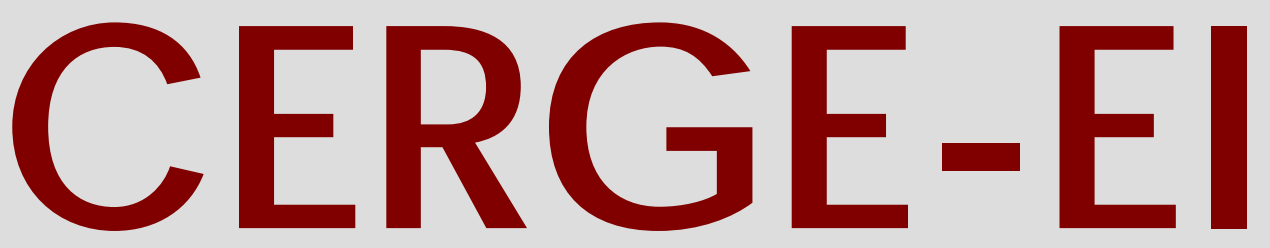

Charles University Centerfor Economic Research and Graduate Education Academy of Sciences of the Czech Republic Ec onomic Institute 


\title{
Working Paper Series 357 (ISSN 1211-3298)
}

\section{The Effect of Mortgage Origination Fees on the Housing Price Dynamics}

\author{
Ashot Tsharakyan
}

CERGE-EI

Prague, August 2008 
ISBN 978-80-7343-157-0 (Univerzita Karlova. Centrum pro ekonomický výzkum a doktorské studium)

ISBN 978-80-7344-146-3 (Národohospodářský ústav AV ČR, v.v.i.) 


\title{
The Effect of Mortgage Origination Fees on the Housing Price Dynamics*
}

\author{
Ashot Tsharakyan ${ }^{\dagger}$
}

CERGE-EI

July 2008

\begin{abstract}
This paper explores the link between mortgage origination fees and housing prices. It is argued that sharp decline in mortgage origination fees in US since the late 1980s was caused by mortgage market deregulation and mortgage innovation. Based on this reasoning the sources of exogenous variation in mortgage fees are identified, and the effect of mortgage fees on housing prices is quantified. The results indicate that decline in mortgage fees had robust statistically significant positive effect on housing prices. The lagged effect of mortgage fees on housing prices is also present.
\end{abstract}

\begin{abstract}
Abstrakt
Tento článek zkoumá vztah mezi poplatky z hypoték a cenami rodinných domů a bytů. V článku tvrdíme, že výrazný pokles $\mathrm{v}$ poplatcích $\mathrm{z}$ hypoték ve Spojených státech na konci osmdesatých let minulého století byl způsoben deregulací trhu s hypotékami a inovacemi $\mathrm{v}$ exogenních faktorech. $Z$ těchto faktorů pak vyvozujeme efekty na ceny bydlení. Výsledky naznačují, že pokles $\mathrm{v}$ poplatcích $\mathrm{z}$ hypoték muel robustní statisticky významný pozitivní efekt na ceny bydlení. Opožděný efekt hypotéčních poplatků na ceny bydlení je rovněž pozorován.
\end{abstract}

Keywords: Mortgage origination fees, housing price, branching restrictions, mortgage market deregulation

JEL classification: R21, R31,C33

\footnotetext{
*Author would like to acknowledge Petr Zemcik for his supervision of this paper and John Muellbauer and Peter Katuscak for useful comments on the earlier drafts

${ }^{\dagger}$ Correspondence address: CERGE-EI, P.O.Box 882, Politických vězňů 7, 11121 Praha1, Prague, Czech Republic. Phone: (+420) 7778312 47, Email: atsharak@cerge-ei.cz

CERGE-EI is a joint workplace of the Center for Economic Research and Graduate Education, Charles University, and the Economics Institute of the Academy of Sciences of the Czech Republic.
} 


\section{Introduction}

The mortgage market is naturally connected with the housing market through a housing demand channel. Among others, one of the important reasons for the increased housing price appreciation in US in the last two decades was the significantly increased availability of mortgages, which made it easier to finance housing purchases and pushed up the demand for housing. Mortgage market deregulation, mortgage innovation, and the extensive involvement of commercial banks in mortgage lending have increased the competition in the mortgage markets and made mortgage lending less risky. This led to a decrease in both mortgage interest rates as well as mortgage origination fees.

Much of the previous research explored the link between mortgage interest rates and housing prices. Abraham and Hendershott (1996) identify the significant negative effect of mortgage interest rates on housing prices using an equilibrium correction model of housing prices . Baffoe-Bonnie (1998) analyzes the dynamic effects of employment ,mortgage interest rates and other key macroeconomic variables on the housing prices and the stock of houses sold on the national and regional levels. Using a vector-autoregressive approach and impulse response functions, the author shows that both the housing price as well as the stock of houses sold are very sensitive to the changes in mortgage interest rates and employment both on the national as well as the regional level. McGibany and Nourzad (2004) analyze short- 
run and long-run relationships between mortgage interest rates and housing prices using advanced non-structural methods. As in previous literature, the authors find a long-run negative relationship between mortgage interest rates and housing prices. However, contrary to previous literature, Granger non-causality tests, impulse response functions, and variance decompositions indicate a small short-run influence from mortgage rates to housing prices. It is worth mentioning that in this paper, which concentrates on the short-run dynamics of housing prices, a mortgage interest rate is included into the housing price regression, and the effect of the mortgage interest rate on the housing price is found to be not very large in magnitude and closer to that found in McGibany and Nourzad (2004).

The effect of mortgage origination fees on housing price dynamics, on the other hand, has not been considered in the previous literature. A change in mortgage origination fees can be another channel through which changes in the mortgage market have affected the US housing market. Mortgage origination fees have to be paid up-front at the time of entering into a mortgage contract and should enter into the total cost of the mortgage for the household. When mortgage orgination fees decrease, the total cost of the mortgage also decreases. Observing the availability of chaper mortgages, households increase demand for housing.

Mortgage origination fees in the US have significantly fallen since the mid-1980s (described in Section 2), which implies that the effect of the decline in mortgage originaton fees on housing price dynamics is worth exploring. Consequently, this 
paper explores the effect of mortgage origination fees on housing prices, controlling for the other fundamentals previously used in the housing price determination literature.

Early studies on the housing price appreciation, which are reviewed in Bartik (1991, Chapter 5), show that housing price appreciation is influenced by population and employment growth. The results of Poterba (1991) indicate that changes in income and construction costs are important in explaining housing prices, but don't provide much support for the role of demographic factors or after-tax user cost in explaining their movements. He also finds that house price movements are predictable on the basis of lagged housing price appreciation and lagged changes in real per capita income. Abraham and Hendershott (1996) study the existence of a bubble in the US housing market using an equlibrium error correction model allowing for a lagged adjustment of housing prices . They show that the real housing price appreciation is positively correlated with the increases in real construction costs, employment, and real income and is negatively correlated with rises in real interest rates. Jud and Winkler (2002) study analyze the determinants of a real housing price change using a sample encompassing 130 metro areas from 1984 through 1998. The model introduces a wealth effect on housing prices, and an MSA fixed-effects model is employed to account for changes in metropolitan-specific construction cost factors. The variables used to explain housing prices include real after-tax mortgage rates, income, population, real wealth, national construction costs, and MSA-specific 
cost factors. The authors find a significant positive effect of stock market wealth accumulation on the housing price changes. They also find a considerable positive effect of construction costs, income and population, and a negative effect of real mortgage rates on housing prices. Finally, lagged changes in real wealth and real construction costs also have a substantial positive effect on housing prices.

Galin (2006) explores the long-run relationship between income and housing prices in a demand/supply framework, and Mikhed and Zemcik (2007) use a structural demand/supply model of the housing market to study the effect of house rents, CPI, and several other already mentioned fundamentals on the housing prices.

This paper analyzes the effect of mortgage origination fees on the housing prices, estimating the housing price regression derived from the demand /supply model analogous to Jud and Wrinkler (2002). Besides mortgage origination fees, which is the key variable of interest, this paper includes also the unemployment rate and user cost into housing price regressions. The analysis is performed using several econometric specifications, including specification with time fixed effects. Also, the endogeneity tests of the explanatory variables are performed and instrumental variable (IV) estimations are employed. Prior to estimating housing price models, the reasons for the decline in mortgage fees are explored. This helps to identify the sources of their supply-side variation exogenous to the housing market.

My results indicate that changes in the mortgage origination fees have had a statistically significant negative effect on housing prices and, along with the other 
variables, have contributed to a substantial housing price appreciation in the US. Also ,the lagged effect of mortgage fees on housing price is found.

The rest of the paper is organized as follows. Section 2 discusses the factors behind the substantial decrease of mortgage origination fees. Section 3 contains the econometric model and description of different specifications. Section 4 contains the data description. Section 5 reports the empirical results. Section 6 contains the endogeneity tests and results of IV estimations. Section 7 concludes the paper.

\section{Mortgage fees}

Mortgage market deregulation, an increased involvement of commercial banks in mortgage lending, the removal of branching restrictions, and mortgage innovation appear to be very important reasons explaining the observed dynamics of mortgage origination fees in the US since the 1980s. Due to these developments, the US mortgage market changed from a locally segmented, heavily regulated market with limited competition to a more competitive, nationally integrated and less risky market.This reasoning allows the belief that those events increased the flow of funds to the mortgage lending activities, which shifted the mortgage market supply curve to the right and together with increased competition led to a significant decrease in mortgage origination fees. This stimulated demand for mortgages and as a result pushed up the demand for housing. At the same time, this reasoning allows the 
identification of a substantial variation in mortgage fees caused by reasons exogenous to the housing market. In this section, the dynamics of mortgage origination fees since the 1980s is described, and the sources of exogenous variation in fees are discussed in detail.

The dynamics of US average initial fees and charges for conventional mortgages from 1980 to 2003 is reported in Figure 1 on page 25. Figure 2-Figure 4 on pages 2526 present the variation in initial fees and charges in the Metropolitan Statistical Areas (MSAs), where the decline of fees was the strongest. Data for initial fees and charges are taken from the Monthly Interest Rate Survey of the Federal Housing Finance Board. The survey reports terms and conditions on all conventional singlefamily, fully amortized, first-time, purchase-money loans closed by major lenders during the last five working days of the month. Reporting institutions include all major types of private mortgage lenders such as savings and loan associations, mortgage companies, commercial banks, and mutual savings banks.The survey excludes FHA-insured and VA-guaranteed loans, multifamily loans, mobile home loans, and refinancing loans. The survey is held monthly and the aggregated yearly data are available from the Federal Housing Finance Board. Initial fees and charges are measured in this survey as a percentage of the mortgage balance.

From Figure 1 it can be seen that from 1980 to 2003 the average initial fees and charges for mortgages in the US decreased from $1.97 \%$ of mortgage balance to only $0.37 \%$ of mortgage balance, which reflects the decrease in relative terms. At the 
same time, the average mortgage amount in the US according to the Monthly Interest Rate Survey increased only 3 times, which implies that mortgage origination fees declined in absolute terms as well. The same can be said about the dynamics of fees in major MSAs, which is plotted in Figure 2 - Figure 4 . For instance, in Atlanta from 1980 to 2003 initial fees and charges decreased from $2.58 \%$ of mortgage balance to $0.31 \%$ of mortgage balance. At the same time the average mortgage amount increased only 2.4 times. In Boston during the same period, fees decreased from 2.12 to $0.23 \%$ of mortgage balance, while the mortgage amount increased only 4 times. In Chicago fees decreased from 2.5 to $0.16 \%$ of mortgage balance, while the mortgage amount increased only 3 times. For reference Figure 5- Figure 6 on page 27 display the evolution of mortgage amounts over this period in those MSAs for which mortgage fees data are provided in Figure 2- Figure 4.

From econometric perspective it is important to analyze the reasons behind the substantial decline of mortgage origination fees. One possibility could be the change over time in the pricing strategy of mortgage lenders towards charging lower fees but compensating them by higher interest rates. This would imply that mortgage origination fees and interest rates should be negatively correlated in the data. To check this possibility, the fixed effects regression of first-differenced initial fees and charges for conventional mortgages on first-differenced mortgage interest rates from the Monthly Interest Rate of Federal Housing Finance Board is performed. The t-statistics of interest rate coefficient in this regression is -0.80 , which implies that 
data do not provide the evidence for such pricing policy.

Another possibility is the occurrence of major supply driven changes in the mortgage market, leading to an increase in competition and supply of funds on it. The inspection of mortgage market developments since the 1980s confirms that the supply side of the mortgage market has undergone major changes both in terms of its structure as well as in the intensiveness of competition in it.

Until the 1980s, specialized depository institutions, mainly savings and loan associations, had the primary role in mortgage lending . They were induced by regulations and tax incentives to the majority of their assets in mortgages and weren't allowed by law to perform commercial banking activities (business loans, consumer credit credit cards, etc.). Moreover, untill 1966 they were excluded from deposit rate ceilings applied to commercial banks, and in 1966 the deposit rate ceilings were extended to saving and loan associations, but they were set higher for those institutions than for commercial banks . Commercial banks, on the other hand, had the major role in business and consumer credit but a limited one in mortgage lending. Deposit rate ceilings ,applied to commercial banks by regulation Q since the 1930s, restricted the maximum interest rate which could be paid by commercial banks for time and saving deposits. Thus, saving and loan associations at first not subject to those restrictions and later subject to milder restrictions, were able to more efficiently raise funds for making mortgage loans than commercial banks were. In essence and mainly due to regulatory reasons, savings and loan associations and 
commercial banks were specialized in different segments of the lending market.

Another factor limiting competition in the mortgage markets was the existence of branching restrictions on both commercial banks as well as savings and loan associations. The National Banking Act of 1863 did not explicitly allow national banks to open new branches, which was interpreted by the Comptroller of the Currency's office as a prohibition. Moreover, laws in the majority of states prohibited any kind of branching whereas in the remaining ones only intracity branching was allowed. By 1924 only 12 states allowed statewide branch banking, but no state allowed existence of any branches of banks based in the other states. This led to a formation of a national banking system consisting of unit banks with no nationwide branching. The national mortgage market became segmented by location, since the local saving and loan associations and commercial banks were isolated from the competition of their counterparts based in the other locations.

The subsequent two decades were described by major changes in the mortgage market. The sharp increase in market interest rates in the late 1970s made deposits subject to interest rate ceilings much less attractive relative to other financial instruments offering a market interest rate. This resulted in a substantial outflow of funds from commercial banks and savings and loan associations and questioned the viability of traditional deposit. In response in 1980 Congress passed a procedure of complete removal of deposit rate ceilings untill 1986. Moreover, to make savings and loan associations more competitive and solvent, the Garn-St.Germain 
Depository Institutions Act was passed in 1982. Savings and loan associations were authorized to make commercial, corporate, business and agricultural loans, borrow money from the Federal Reserve, and to issue credit cards. In a deregulated environment with a range of new profit opportunities, a large number of new savings and loan associations appeared on the market and competition became more fierce. As it can be seen in Figure 1-Figure4, increased competition led to a decrease in mortgage origination fees during 1982-1984. However, in an effort to take advantage of high interest rates and the increased range of activities, savings and loan associations made a lot of incompetent investments in risky and fraudulent ventures and lent much more money then they should have. As a result starting from 1985, the savings and loan industry found itself in a severe crisis and more than 1,000 savings and loan institutions failed and became insolvent.

Right after the crisis of the savings and loan industry, commercial banks started to increase their presence in the mortgage market at a very high rate. Between 1987 and 1997, the amount of outstanding mortgages by US commercial banks grew at an average annual rate of $10.6 \%$, raising their share of the market from $13.4 \%$ to $19.8 \%$. This happened due to several reasons. First, the increased popularity of commercial papers such as promissory notes, certificates of deposit, drafts etc. in the 1980s and 1990s decreased the role of commercial banks in business and consumer credit. Due to the reduced cost of borrowing through the commercial papers, many firms and consumers were able to satisfy their borrowing needs without going to the bank. 
If in 1987 banks lent to non-financial firms $\$ 7$ for every $\$ 1$ these firms borrowed in the commercial paper market, by 1997 they lent only $\$ 4$ for every $\$ 1$. Apparently, commercial banks searched for substitute for the lost business, and crisis condition of the savings and loan industry made the mortgage market very attractive to them. Secondly, since the 1989 Federal Home Loan Bank (FHLB) system became open to commercial banks. FHLB system provides billions of dollars of primary liquidity to approximately $80 \%$ of the nation's financial institutions. Banks that join FHLB receive access to a wide range of low-cost services, including the various types of loans. The opportunity to join FHLB and receive corresponding benefits has further boosted the mortgage lending activities of the commercial banks. Finally, in late the 1980s many banking organizations acquired savings and loan associations with the purpose of expanding their retail activities. The rapidly increasing involvement of the large number of commercial banks increased the competition and supply of funds in the mortgage market. This explains why mortgage origination fees did not rise very sharply in 1985-1987 and gradually decreased from the end of 1980s.

Another important development which further reinforced the competition and the supply of funds in the mortgage market was the evolvement of interstate nationwide banking because of the gradual removal of state branching restrictions. Table 1 on page 28 contains the year of the removal of branching restrictions for each state. According to the table, from 1960 to 1979, sixteen states removed the branching restrictions, and from 1980 to 1999 thirty five states did so. Thus, in 1980s and 
1990s competition in the majority of state-level mortgage markets became more intense since the banks and savings and loan associations were allowed to open new branches in the other states. Furthermore, in the states where branching restrictions were removed prior to 1987 , this effect should have been the strongest since by the time commercial banks got actively involved in mortgage lending, they were already well established in those locations. The increased competition and supply of funds in the local markets further contributed to the downward trend in mortgage origination fees, which is evident from Figure 1-Figure 4.

Finally, one of the most important causes of the decrease in mortgage fees in the 1990s was large number of innovations in the mortgage industry that increased the liquidity and decreased the riskiness of mortgage loans. The development of creditscoring models has enabled quicker and more accurate evaluation of prospective borrowers. Securitization programs, which make possible the packaging and selling of loans to the secondary market have greatly improved the liquidity of mortgages. They can now be quickly moved off of bankers' balance sheets and are thus much less risky. Developments in information technologies have greatly reduced the mortgage origination costs incurred by the lenders. Due to the use of E-mail and fax machines, the time of assembling the information needed for an underwriting decision and sharing it with credit bureaus, title companies appraisers insurers, etc. has significantly decreased . Furthermore, the appearance of a "paperless" mortgage dramatically reduced the amount of time between closing the loan and 
securitization. These developments have considerably decreased the transaction costs of mortgage origination. Since mortgage origination fees charged by the lender should be based both on transaction costs as well as the riskiness of the loan, it is natural to expect that a decrease in risk and transaction costs should lead to a decrease in fees.

\section{Econometric model}

The model employed in this research is a demand/supply model of housing prices, analogous to Jud and Winkler (2002). The demand for housing in the Metropolitan Statistical Area (MSA) $j$ at time $t$ is given by the following equation :

$$
Q_{j, t}^{D}=D\left(P_{j, t}, F_{j, t} I_{j, t}, Y_{j, t}, P_{o p} p_{j, t} U R_{j, t}, U C_{j, t}, W_{i, t}, u_{j, t}\right)
$$

where $P$ is the real price of housing, $F$ are the mortgage origination fees ( as a percentage of mortgage balance), $I$ is the real mortgage interest rate, $Y$ is the real income, $P o p$ is the population, $U R$ is the unemployment rate, $U C$ is the user cost of housing, $W$ is the real wealth (stock market wealth), and $u$ is the random error.

Market supply is defined by the following equation :

$$
Q_{j, t}^{S}=S\left(P_{j, t}, C C_{j, t}, M_{j, t}, v_{j, t}\right),
$$


where $P$ is the real price of housing, $C C$ is the real construction cost, $M$ are the MSA-specific cost factors, and $v$ is the random error.

By equating the demand and supply equations, one can derive the equation for the housing price :

$$
P=f\left(F_{j, t} I_{j, t}, Y_{j, t}, P o p_{j, t} U R_{j, t}, U C_{j, t}, C C_{j, t}, M_{j, t}, W_{i, t}, \varepsilon_{j, t}\right) .
$$

To insure stationarity, the data is first-differenced and before differencing, logarithmic transformation is applied to all the variables except mortgage fees,the unemployment rate, and the user cost (which are defined in terms of percentages). The stationary of each variable after the performed transformations is confirmed by Im-Pesaran-Shin stationarity test results presented in Table $2^{1}$ on page 29 . After the described transformations, the following regression equation is derived :

$$
\begin{aligned}
\Delta \log P_{j, t}= & \text { const }_{j}+\alpha_{1} \Delta F_{j, t}+\alpha_{2} \Delta \log I_{j, t}+\alpha_{3} \Delta \log Y_{j, t}+\alpha_{4} \Delta \log P_{o p_{j, t}}+ \\
& +\alpha_{5} \Delta U R_{j, t}+\alpha_{6} \Delta U C_{j, t}+\alpha_{7} \Delta \log C C_{t}+\alpha_{8} \Delta \log W_{t}+a_{j}+\varepsilon_{j, t}(1)
\end{aligned}
$$

where $a_{j}$ stands for the MSA fixed effects. The $C C$ variable here captures the effect of national changes in real construction costs on the growth rate of housing prices . The effect of changes in MSA-specific cost factors $\left(\Delta M_{j, t}\right)$ on the growth rate of housing prices is captured by MSA fixed effects (based on Jud and Winkler,

\footnotetext{
${ }^{1}$ Since the construction cost and real wealth are time series but not panel variables, their stationarity was tested by means of the Dickey-Fuller test, which confirmed stationaity of these variables in terms of difference in logs.
} 
2002). The MSA-specific cost factors, which can intuitively affect the growth rate of housing prices, are related to local regulatory restrictions on new construction and local limitations on availability of land. The change in local regulatory restrictions and limitations on the availability of land over time can increase or decrease the rate of new construction and in the case of rising demand can accelerate the growth rate of prices. The demand/supply framework with first differences allows a focus on short-run effects of the explanatory variables.

Equation (1) is estimated by means of the fixed -effects estimation procedure. The standard errors of the coefficients are corrected for possible autocorrelation and heteroskedasticity in the data by means of the heteroscedasticity robust ${ }^{2}$ estima- $^{-}$ tion and clustering by MSA. In addition to equation (1), the same specification supplemented by year dummies is estimated. This takes out the national time variation and allows separation of the MSA specific time variation. In this specification, dummy variables capture the effects of nationwide, only time varying variables, which drop out.

The expected sign of population, income, wealth and construction cost in these regressions is positive. While the first three variables are positively correlated with housing demand and consequently housing price, the construction cost is negatively correlated with housing supply. Lower housing supply resulting from higher construction costs should lead to higher housing prices and vice versa. The expected

\footnotetext{
${ }^{2}$ Specifying option 'robust' for regression in Stata produces heteroskedasticity robust variance estimator and White's heteroskedasticity-robust standard errors.
} 
sign of mortgage fees according to the hypothesis is negative. The expected signs of user cost, unemployment rate and mortgage interest rate is also negative. The user cost represents the opportunity cost of owning a housing stock. When the user cost decreases, the housing demand should increase and the housing price should go up as well. A high unemployment rate, on the other hand, indicates a recession in the economy and causes housing demand and the housing price to fall. The next section reports the results of estimations.

\section{Data description}

The dataset used for estimation covers 30 MSAs in the period from 1982 to 2003. The real price of housing is represented by the Housing Price Index (HPI) from the Office of Federal Housing Enterprise Oversight (OFHEO) deflated by MSAspecific CPI. MSA level CPI is available from the Bureau of Labor Statistics for 23 MSAs of the sample and for the remaining ones the corresponding regional CPI is used. Mortgage fees are initial fees and charges on conventional mortgages available from the Monthly Interest Rate Survey of the Federal Housing Finance Board and measured as the percentage of mortgage balance. The real interest rate on mortgages is represented by contract interest rates from the Monthly Interest Rate Survey of Federal Housing Finance Board, which are adjusted for inflation using the MSA level CPIs.

Real income is measured by per capita personal income from the Bureau of 
Economic Analysis, adjusted by the corresponding CPI. MSA-level population is also reported by the Bureau of Economic Analysis. The unemployment rate is taken from the local area unemployment statistics of the Bureau of Labor Statistics (BLS). Construction cost is approximated by the construction component of the Producer Price Index (reported by BLS) deflated by CPI-U. The real stock market wealth variable constitutes the S\&P500 deflated by CPI-U. Finally, direct user cost from Galin (2004) is used as a measure of the user cost of housing. The formula for direct user cost is given by :

$$
C=\left(i+\tau^{p}\right)\left(1-\tau^{y}\right)+\delta,
$$

where $i$ is the real interest rate, $\tau^{p}$ is the property tax , $\tau^{y}$ is the income tax, and $\delta$ is the depreciation rate.

The long-term (10 years ) US government bond yield from the IMF International Financial Statistics deflated by the local CPI is employed as the real interest rate. State property taxes are taken from Emrath (2002). The 1990 Census property taxes are used for the period 1980-1989 and 2000 Census property taxes are used for the remaining years. Finally, income taxes from the TAXSIM model of the National Bureau of Economic Research and $\delta=0.025$ (Harding, Rosenthal and Sirmans, 2004) are used to calculate the user cost. 


\section{Empirical results}

The results of the regressions using Specification (1)-Specification (2) are presented in Table 3 on page 30 . All the standard errors are corrected for autocorrelation and heteroscedasticity. As expected, in both specifcations the coefficient of initial fees and charges is statistically significant at 5\% level and negative. All the other variables also have the expected signs, and coefficients are mostly significant. In the benchmark specification, the coefficient of fees is -0.024 and t-statistics is 2.59 .Since the dependent variable is determined in terms of difference in logs and fees are determined in terms of differenece in levels, this is log-level specification. Consequently, the decrease in mortgage origination by 1 percentage point leads to an increase in housing prices by $100 * 0.024=2.4$ percent. In contrast to Poterba (1991), in my dataset the user cost has a significant negative effect on housing prices. The unemployment rate has the expected sign and the statistical significance in specification with year dummies is included. Mortgage interest rates are significant in regression without year dummies but loose their significance in specifications with year dummies, which is due to the fact that they don't vary much across MSAs. Moving towards a more general specification decreases the coefficient on fees to -0.014 in Specification (2) , but still leaves it statistically significant at the $5 \%$ level, which demonstrates the robustnes of the observed effect of fees on housing prices.

The observed results allow us to conclude that the negative change in mortgage 
origination fees has a positive effect on housing price changes. However, in the previous regressions the possibility of a lagged effect of fees is not explored. Another point is that other explanatory variables can also have a lagged effect on housing prices. Thus, in Table 4 page 31, the results of the regressions allowing lagged adjustments of explanatory variables, are displayed. In those tables, lags found statistically significant are included. The results indicate significant lagged effects of initial fees and charges in specification (1)-(2). It is possible to conclude from the observed results that a lagged effect of fees on housing prices is present in the data. The results also indicate lagged effects of the user cost, the unemployment rate, the construction cost, and the S\&P 500. The statistical significance of fees, however, remains robust to the inclusion of relevant lags of other explanatory variables.

Since both current as well as lagged fees have a statistically significant effect on the housing price, the same specifications but with two year-moving averages are also estimated. In specification (1) the coefficient on moving average of fees is given by -0.048 , and in specification (2) it is given by -0.032 . In both cases, the moving average of fees becomes significant even at the $1 \%$ level.

\section{Endogeneity issues and IV estimations}

In the previous sections, it was argued that changes in mortgage origination fees were mainly driven by the increase in the supply of mortgages due to reasons 
exogenous to the housing market, and the effects of exogenous variation in fees on the housing prices were quantified. Observing the dynamics of fees and housing prices, one can conclude that supply side factors were more significant since the supply story of the mortgage market is consistent with falling mortgage fees and rising housing prices.

However, an alternative story can also be considered. Suppose that due to some reasons ( for instance growth of the population in a given location or income growth) demand for housing increases. On the one hand, this generates an increase in the housing price, but on the other hand, it increases the demand for mortgages and drives up the mortgage origination fees. This causes the simultaneity in housing prices and mortgages fees, and creates a bias in coefficient of fees. In this case, variation in fees is endogenous to the housing market .

To prove the validity of the previous arguments about the exogeneity of fees and reject the alternative story, the endogeneity of fees is tested for, using the endogeneity test (described in 'Introductory Econometrics by Wooldridge) equivalent to the Hausman specification test. The algorithm of endogeneity test is the following: the suspected variable is regressed on all instrumental variables and exogenous variables; the residuals from this regression are obtained; the obtained residuals are added to the housing price equation, and the significance of residuals in the housing price regression is tested for by means of a t-test. If the residuals are statistically different from zero, the variable is endogenous. One of the instruments for mort- 
gage fees is generated based on the change in branching restrictions. Intuitively, the removal of branching restrictions on commercial banks and savings and loan associations allows them to expand geographically , which increases the availability of mortgages and competition in each location and decreases the mortgage fees. Using Table 1, which reports on the year of removing of branching restrictions in each state, the corresponding dummy variable is generated. This variable takes value 0 for each year when the state to which the given MSA belongs had branching restrictions and value 1 for the year of removing the branching restrictions and all the subsequent years. The results of instrumenting regressions in which lags of independent variables are included together with a branching dummy, are reported in Table 5 on page 32 . It demonstrates that mortgage fees are strongly correlated with the branching dummy, lag of fees, and lag of income. Consequently, these variables are used as instruments. The t-statistics of residuals' coefficient in housing price regression is 1.09 (Table 8) which implies that there is no evidence of endogenous variation in fees, and previous arguments are confirmed.

The same procedure as described above is employed for testing the endogeneity of the remaining explanatory variables. The results of instrumenting regressions for mortgages interest rates and income (variables found endogenous), are reported in Table 6-Table 7. Based on these regressions, first lags of explanatory variables are used as instruments. The t-ratios for corresponding residuals are reported in Table 8 on page 35 . The results indicate that interest rates and income are endogenous since 
the corresponding residuals are statistically significant. Thus, these variables need to be instumented. The results of IV regressions in Specification (1)-Specification(2) are reported in Table 9 . It can be seen from Table 9 that coefficients of mortgage fees are not changed much and are still negative and statistically significant.

\section{Summary}

This paper explores the effects of changes in mortgage origination fees on housing prices. It identifies the major supply side factors on the mortgage market, which have driven a sharp decline in mortgage fees during the last two decades. Using the reasoning that observed supply side changes in the mortgage market are exogenous to the housing market, the effect of mortgage origination fees on housing prices is quantified. The most general set of regressors employed in the previous housing price literature is used together with different econometric specifications, including the ones allowing for lagged adjustment in independent variables. The results demonstrate that negative changes in mortgage origination fees have a statistically significant positive effect on housing prices. The instrumental variable approach is also used to prove the robustness of results to endogeneity issues. It is shown that in the case of accounting for possible endogenous variation in mortgage fees and other explanatory variables, the negative effect of fees on the housing prices remains significant. 


\section{References}

[1] Abraham, J. M., Hendershott, P.H., "Bubbles in Metropolitan Housing Markets", Journal of Housing Research, 1996, 7:2, 191-208

[2] Baffoe-Bonnie, J., " The Dynamic Impact of Macroeconomic Aggregates on Housing Prices and Stock of Houses: A National and Regional Analysis", The Journal Of Real Estate Finance And Economics, Vol. 17, 1998

[3] Bartik, T. J., "Who Benefits from State and Local Economic Development Policies?", Kalamazoo, MI: W. E. Upjohn Institute, 1991

[4] Beck,T., Levine, R., "Big bad banks?The Impact of U.S. Branch Deregulation on Income Distribution", NBER Working Paper Series, Working Paper 13299

[5] Doms, S.M., Krainer, J., "Innovations in Mortgage Markets and Increased Spending on Housing" FEDERAL RESERVE BANK OF SAN FRANCISCO, WORKING PAPER SERIES, Working Paper 2007-05

[6] Jud,G.D., Winkler, D.T., "The Dynamics o f Metropolitan Housing Prices", Journal of Real Estate Research, Vol. 23 Nos. $1 / 2$ - 2002, 30-50

[7] McGibanny, J., Nourzad, F., " Do lower mortgage rates mean higher housing prices" , Applied Economics , Vol. 34,2004

[8] Poterba, J. M.," House Price Dynamics: The Role of Tax Policy and Demography", Brookings Papers on Economic Activity, 1991, 2, 143-199

[9] Van Order, R. " The U.S. Mortgage market : The model of dueling characters" Journal of Housing Research, 2000, 11:2, 233-255 
Figure 1: Dynamics of initial fees and charges for conventional mortgages in the US

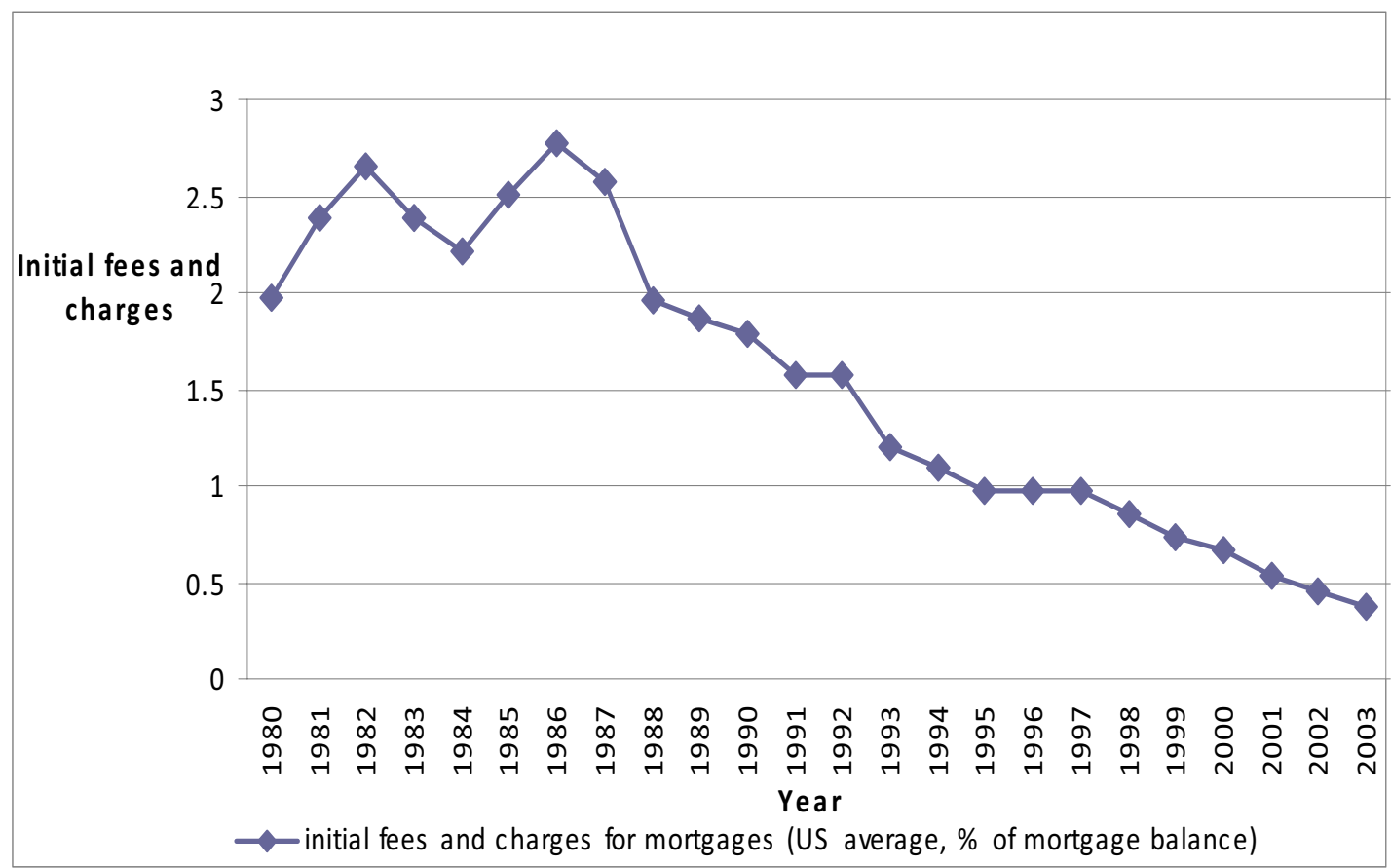

Figure 2: Dynamics of initial fees and charges in individual MSAs $1 / 3$

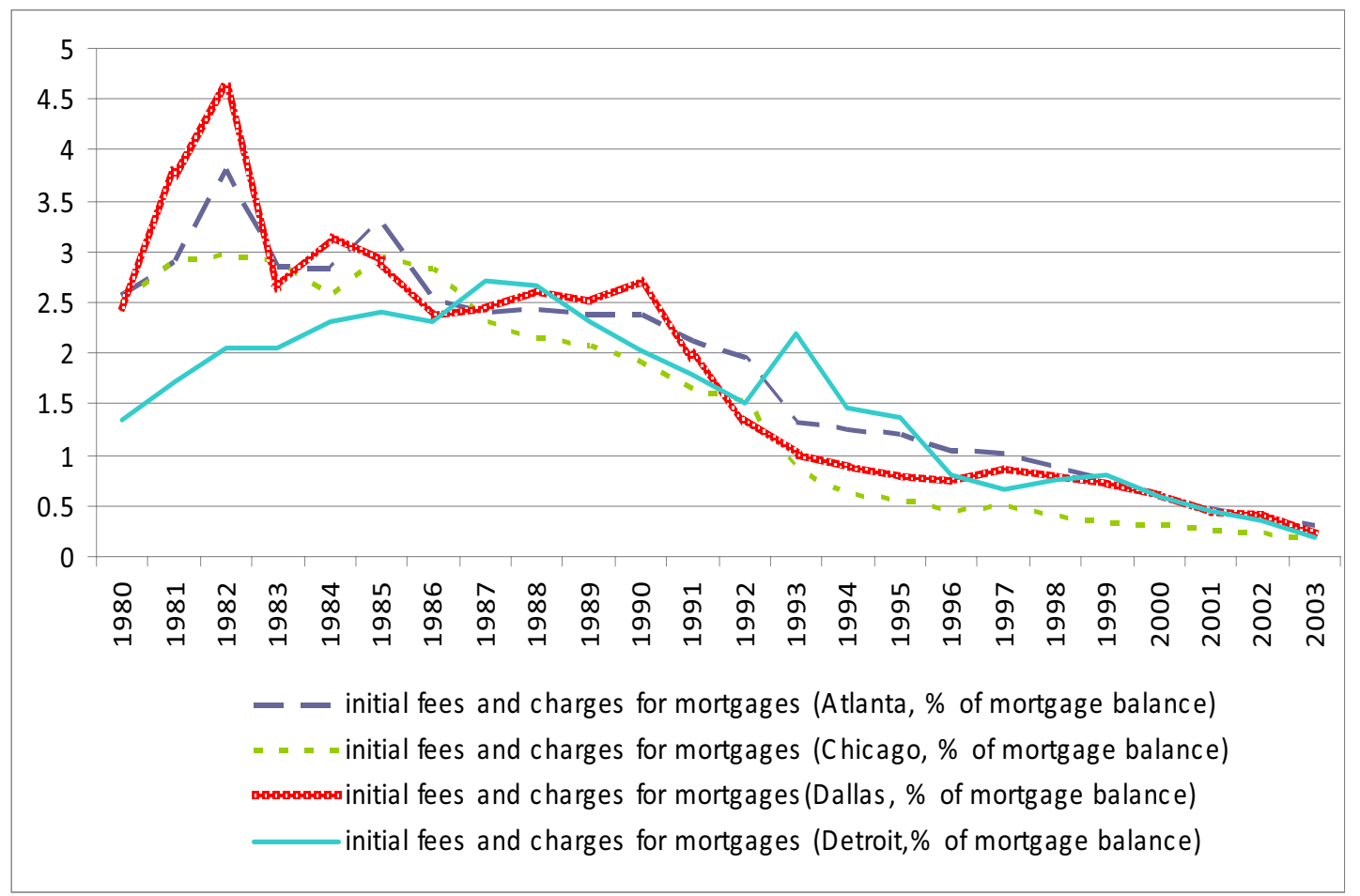


Figure 3: Dynamics of initial fees and charges in individual MSAs 2/3

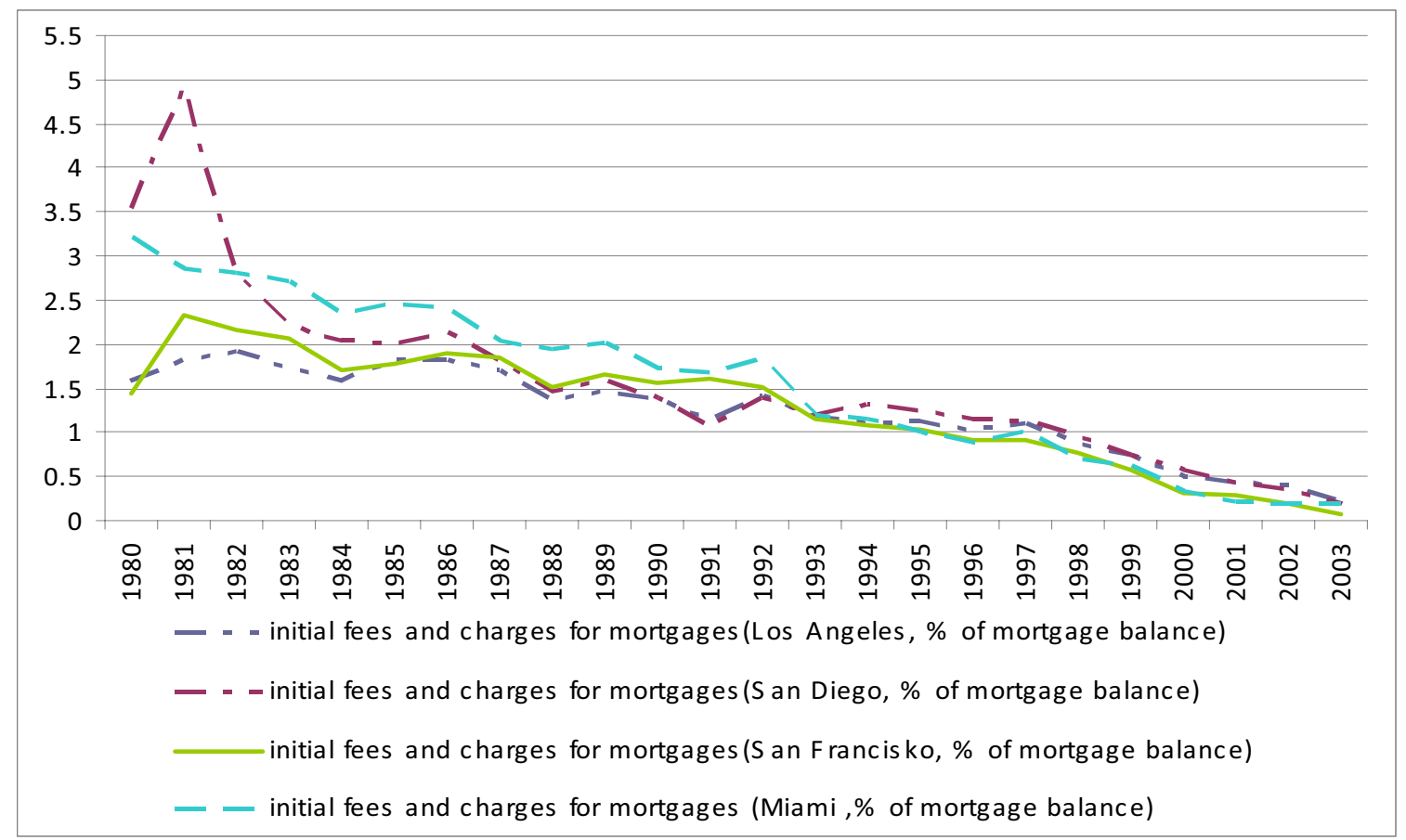

Figure 4: Dynamics of initial fees and charges in individual MSAs 3/3

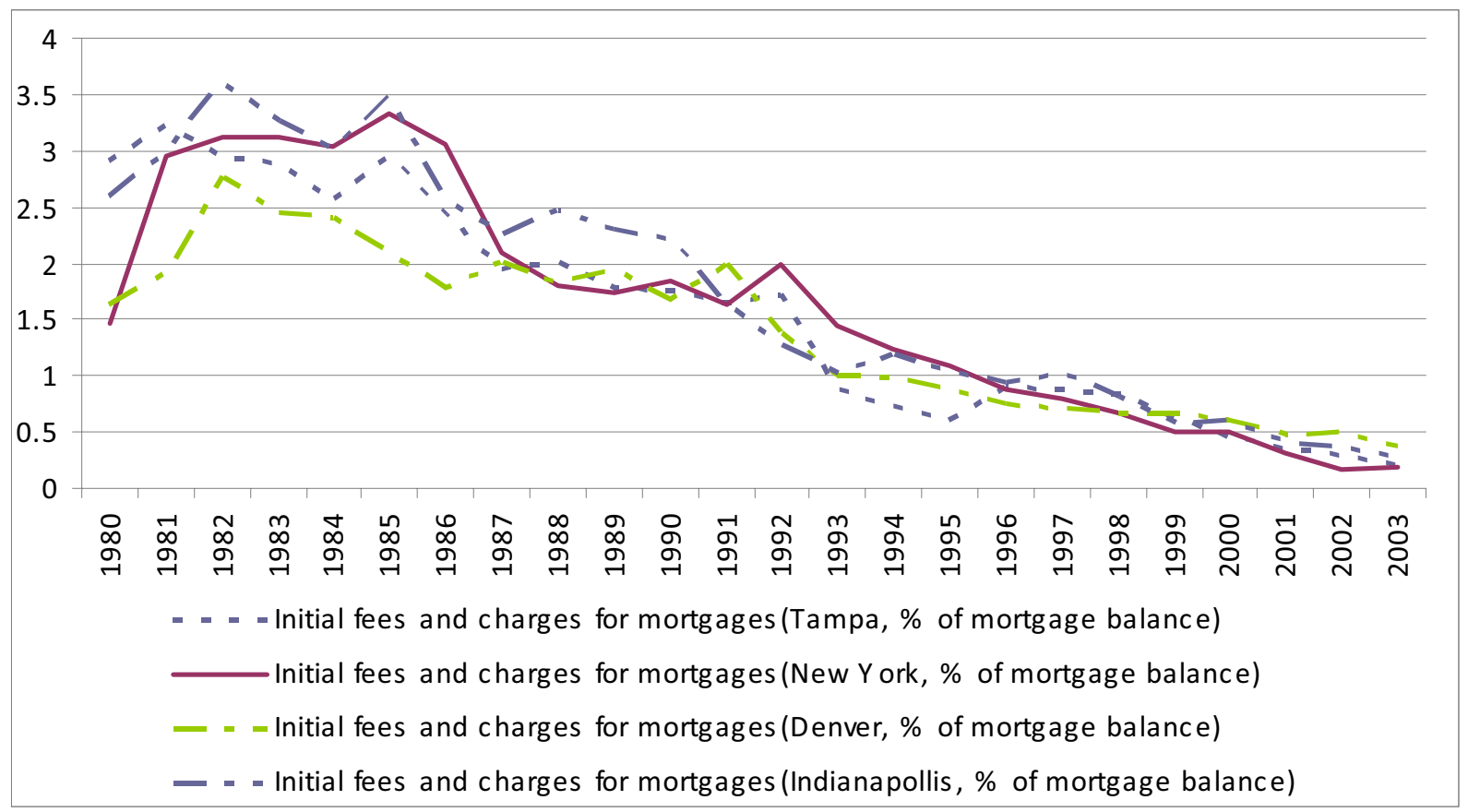


Figure 5: Evolution of average mortgage amounts in individual MSAs 1/2

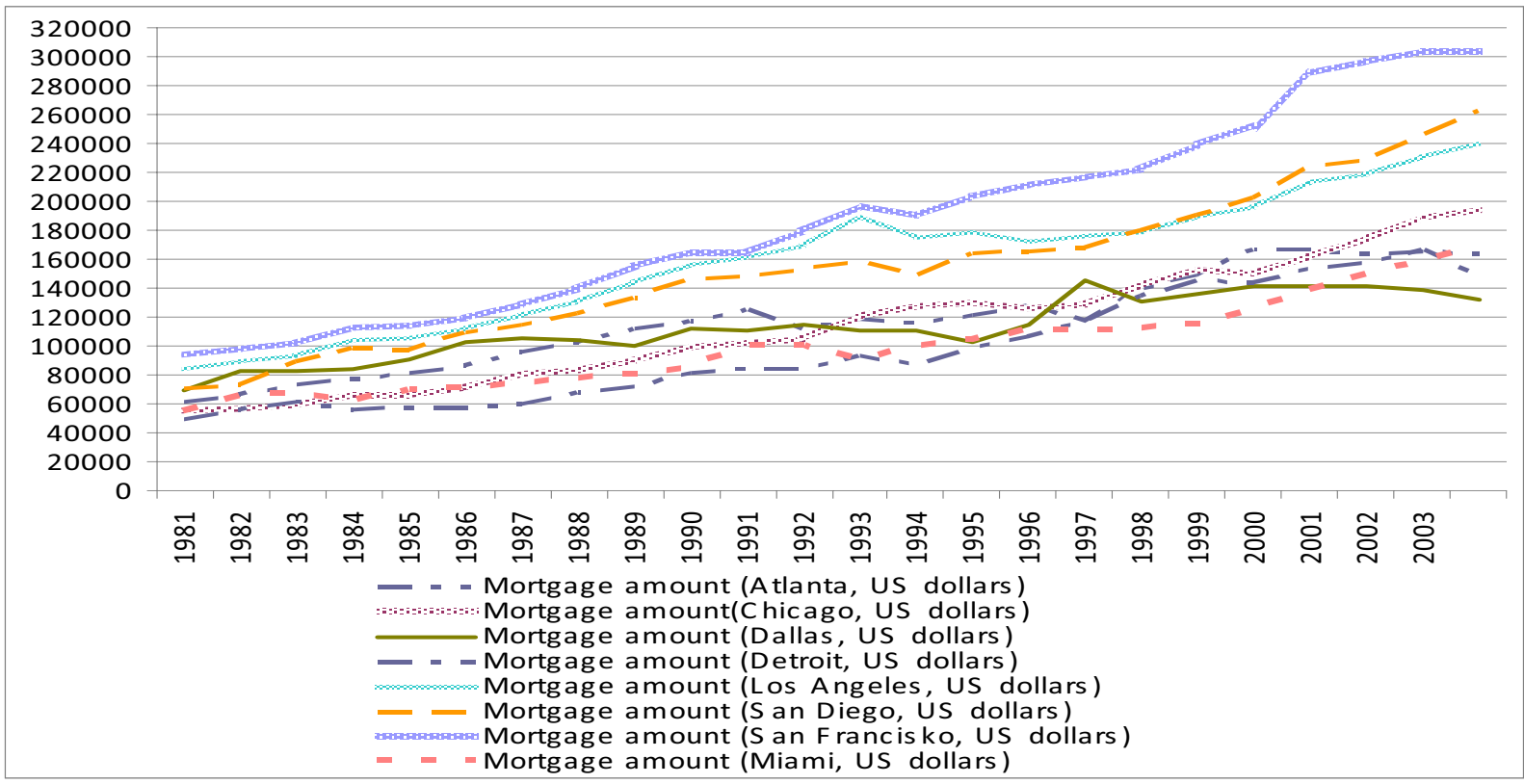

Figure 6: Evolution of average mortgage amounts in individual MSAs 2/2

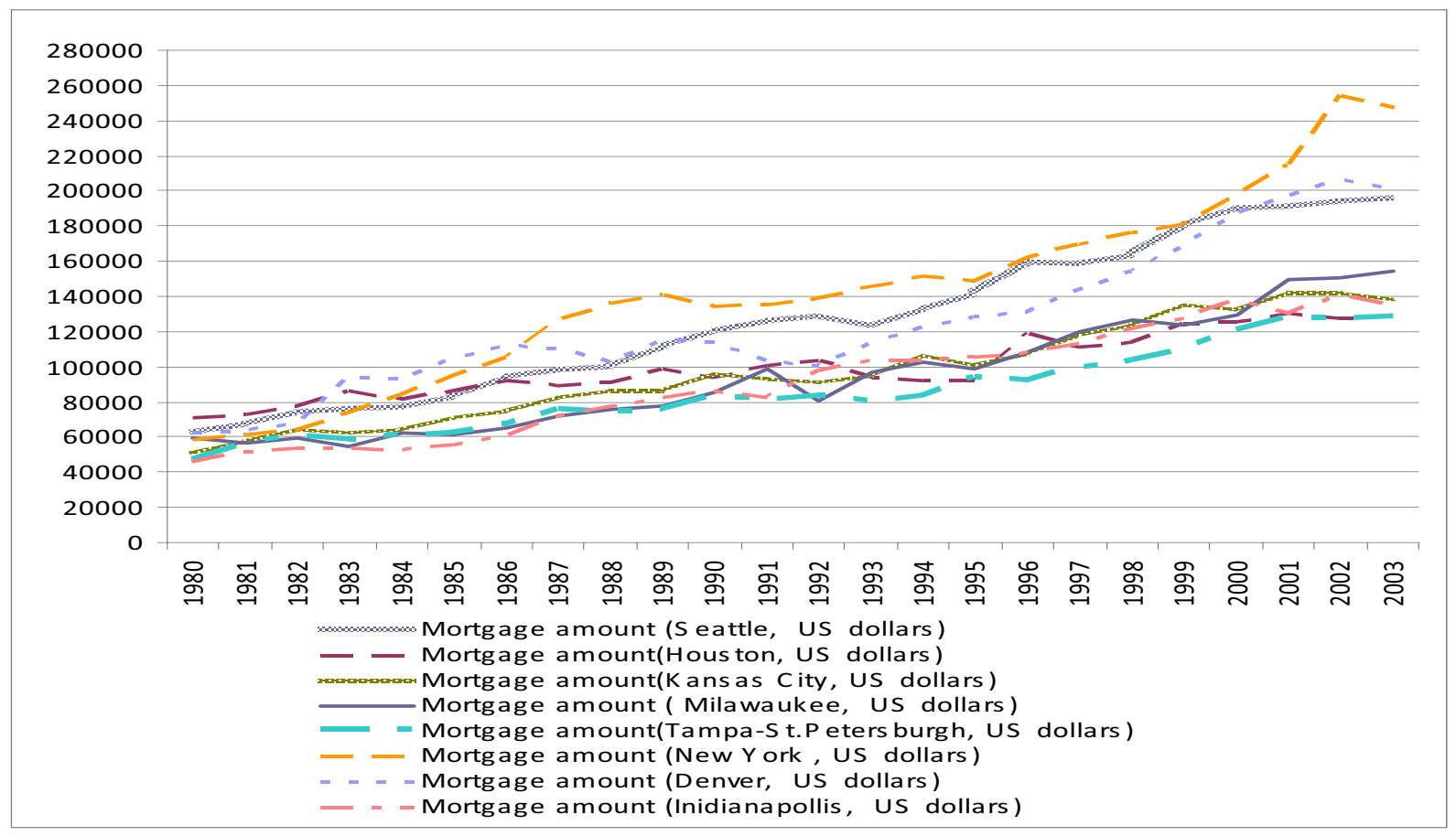


Table 1: Year of removal of branching restrictrion by state

\begin{tabular}{|l|l|l|l|}
\hline State & Year of removal & State & Year of removal \\
\hline Alabama & 1981 & Missouri & 1990 \\
\hline Alaska & 1960 & Montana & 1990 \\
\hline Arizona & 1960 & Nebraska & 1985 \\
\hline Arkansas & 1994 & Nevada & 1960 \\
\hline California & 1960 & New Hampshire & 1987 \\
\hline Colorado & 1991 & New Jersey & 1977 \\
\hline Connecticut & 1980 & New Mexico & 1991 \\
\hline District of Columbia & 1960 & New York & 1976 \\
\hline Florida & 1988 & North Carolina & 1960 \\
\hline Georgia & 1983 & North Dakota & 1987 \\
\hline Hawaii & 1986 & Ohio & 1979 \\
\hline Idaho & 1960 & Oklahoma & 1988 \\
\hline Illinois & 1988 & Oregon & 1985 \\
\hline Indiana & 1989 & Pennsylvania & 1982 \\
\hline Iowa & 1999 & Rhode Island & 1960 \\
\hline Kansas & 1987 & South Carolina & 1960 \\
\hline Kentucky & 1990 & Tennessee & 1985 \\
\hline Louisiana & 1988 & Texas & 1988 \\
\hline Maine & 1975 & Utah & 1981 \\
\hline Maryland & 1960 & Vermont & 1970 \\
\hline Massachusetts & 1984 & Virginia & 1978 \\
\hline Michigan & 1987 & Washington & 1985 \\
\hline Minnesota & 1993 & West Virginia & 1987 \\
\hline Mississippi & 1986 & Wisconsin & 1990 \\
\hline & & Wyoming & 1988 \\
\hline Sourc: Beck & & \\
\hline
\end{tabular}

*Source: Beck, Levine, Levkov (2007) 
Table 2 : Stationarity test results ( Pesaran's unit root test in the presence of cross-sectional dependence, version with constant and trend )

\begin{tabular}{|l|l|l|l|l|l|}
\hline Variable & Transformation & t-bar statistics & Cv. 10\% & Cv. 5\% & Cv. 1\% \\
\hline Price index & first difference in logs & -2.872 & -2.580 & -2.670 & -2.830 \\
\hline Fees & first difference in levels & -3.775 & -2.580 & -2.670 & -2.830 \\
\hline Income & first difference in logs & -2.792 & -2.580 & -2.670 & -2.830 \\
\hline Population & first difference in logs & -2.859 & -2.580 & -2.670 & -2.830 \\
\hline User cost & first difference in levels & -3.095 & -2.580 & -2.670 & -2.830 \\
\hline Unempl. rate & first difference in levels & -2.751 & -2.580 & -2.670 & -2.830 \\
\hline Mortgage rate & first difference in logs & -3.989 & -2.580 & -2.670 & -2.830 \\
\hline
\end{tabular}

Under the null hypothesis, the series is non-stationary. Cv. stands for the critical value . Construction cost and real wealth are time series but not panel variables. Their stationarity was tested by means of the Dickey-Fuller test. 
Table 3: The realtionship between mortgage origination fees and housing prices

\begin{tabular}{lcc}
\hline Independent Variable & Specification (1) & Specification $(2)$ \\
\hline \hline Interest rate on mortgages & -.033 & -.026 \\
& $(.015)$ & $. .034)$ \\
Mortgage fees & -.024 & -.014 \\
& $(.009)$ & $(.006)$ \\
Population & 2.658 & 2.152 \\
& $(.357)$ & $(.399)$ \\
Income & .499 & 1.005 \\
& $(.118)$ & $(.184)$ \\
User cost & -.472 & -.291 \\
& $(.126)$ & $(.135)$ \\
Unemployment rate & -.004 & -.005 \\
\multirow{2}{*}{ S\&P 500 } & $(.002)$ & $(.002)$ \\
& .031 & \\
Construction cost & $(.007)$ & \\
& .404 & \\
Constant & $(.118)$ & \\
& -.0008 & -.097 \\
$\mathrm{~N}$ & $(.009)$ & $(.018)$ \\
\hline
\end{tabular}

In Specification(2), year dummies are included. Since there is a constant in the regression, year dummies start from the year 1985 (two years of observations lost before estimation due to first differencing and using lags of differences). Standard errors are displayed in parentheses. The dependent variable is the housing price index ( first difference in logs). Estimated using fixed effects estimation (dif-in-dif estimator) . Clustering by MSA and heteroskedasticity robust estimation (White's standard errors) is used to account for potential heteroskedasticity and autocorrelation in the data. 
Table 4: The relationship between mortgage fees and housing prices in the case of allowing a lagged adjustment in the independent variables

\begin{tabular}{|c|c|c|}
\hline Independent Variable & Specification(1) & Specification $(2)$ \\
\hline \multirow[t]{2}{*}{ Interest rate on mortgages } & -.053 & -.048 \\
\hline & $(.027)$ & $(.036)$ \\
\hline \multirow[t]{2}{*}{ Mortgage fees } & -.024 & -.014 \\
\hline & $(.009)$ & $(.006)$ \\
\hline \multirow[t]{2}{*}{ Lagged mortgage fees } & -.026 & -.0185 \\
\hline & $(.009)$ & $(.006)$ \\
\hline \multirow[t]{2}{*}{ Population } & 1.429 & 1.306 \\
\hline & $(.603)$ & $(.476)$ \\
\hline \multirow[t]{2}{*}{ Income } & .657 & .757 \\
\hline & $(.111)$ & $(.155)$ \\
\hline \multirow[t]{2}{*}{ User cost } & -.690 & -.441 \\
\hline & $(.150)$ & $(.186)$ \\
\hline \multirow[t]{2}{*}{ Lagged user cost } & -.234 & -.379 \\
\hline & $(.119)$ & $(.129)$ \\
\hline \multirow[t]{2}{*}{ Unemployment rate } & -.003 & -.005 \\
\hline & $(.002)$ & $(.003)$ \\
\hline \multirow[t]{2}{*}{ Lagged unemployment rate } & & -.005 \\
\hline & & $(.002)$ \\
\hline \multirow[t]{2}{*}{ S\&P 500} & .048 & \\
\hline & $(.009)$ & \\
\hline \multirow[t]{2}{*}{ Lagged S\&P 500} & .093 & \\
\hline & $(.018)$ & \\
\hline \multirow[t]{2}{*}{ Construction cost } & .448 & \\
\hline & $(.162)$ & \\
\hline \multirow[t]{2}{*}{ Lagged construction cost } & .818 & \\
\hline & $(.143)$ & \\
\hline \multirow[t]{2}{*}{ Constant } & .013 & -.115 \\
\hline & $(.011)$ & $(.020)$ \\
\hline $\mathrm{N}$ & 600 & 600 \\
\hline
\end{tabular}


Table 5 : Instrumenting regression for mortgage fees

\begin{tabular}{lc}
\hline Independent Variable & \\
\hline \hline Branching dummy & -.051 \\
& $(.015)$ \\
Lag of interest rate & -.035 \\
& $(.106)$ \\
Lag of mortgage fees & -.182 \\
& $(.046)$ \\
Lag of population & -1.226 \\
Lag of income & $(1.478)$ \\
Lag of user cost & .870 \\
Lag of unemployment rate & $(.433)$ \\
Lag of construction cost & .570 \\
Lag of S\&P 500 & $(.883)$ \\
& $(.0124)$ \\
& $(.788)$ \\
& .052 \\
& $(.080)$ \\
& -.158 \\
& $(.032)$ \\
\hline
\end{tabular}

The dependent variable is the first difference of mortgage fees. Fixed effects estimation with clustering and option robust is used . Standard errors are reported in parenthesis 
Table 6: Instrumenting regression for mortgage interest rates

\begin{tabular}{lc}
\hline Independent Variable & \\
\hline \hline Branching dummy & -.038 \\
& $(.016)$ \\
Lag of interest rate & -.190 \\
& $(.021)$ \\
Lag of mortgage fees & -.015 \\
& $(.009)$ \\
Lag of population & -.838 \\
Lag of income & $(.309)$ \\
Lag of user cost & .008 \\
Lag of unemployment rate & -.023 \\
Lag of construction cost & $(.003)$ \\
Lag of S\&P 500 & -.033 \\
& $(.136)$ \\
& $(.650)$ \\
& .023 \\
& $(.080)$ \\
& -.251 \\
& $(.081)$ \\
\hline
\end{tabular}


Table 7: Instrumenting regression for income

\begin{tabular}{lc}
\hline Independent Variable & \\
\hline Lag of interest rate & -.011 \\
& $(.005)$ \\
Lag of mortgage fees & -.016 \\
& $(.008)$ \\
Lag of population & 0.542 \\
& $(.387)$ \\
Lag of income & .865 \\
& $(.205)$ \\
Lag of user cost & -.033 \\
Lag of unemployment rate & -.057 \\
& $(.024)$ \\
Lag of construction cost & 1.245 \\
Lag of S\&P 500 & $(.730)$ \\
& .182 \\
& $(.083)$ \\
& -.0363 \\
& $(.125)$ \\
\hline
\end{tabular}


Table 8 . Results of endogeneity tests

\begin{tabular}{llll}
\hline \hline Tested variable & Coefficient of residuals & Standard Error & t-statistics \\
\hline \hline Mortgage fees & .029 & .027 & 1.09 \\
Population & -1.106 & .723 & -1.53 \\
Income & .636 & .236 & 2.69 \\
Interest rate & .130 & .059 & 2.20 \\
User cost & -.194 & .400 & -0.49 \\
Unemployment rate & -.018 & .015 & -1.17 \\
\hline Construction cost & 0.816 & 0.552 & 1.47 \\
\hline S\&P 500 & 0.357 & 0.256 & 1.34 \\
\hline
\end{tabular}

This table reports the results of endogeneity tests. Each variable is regressed on the instruments and exogenous variables. The residuals from these regressions are obtained and incorporated into the housing price regression in the most general specification. The coefficients and standard errors of the residuals in the housing price regression are reported in the table. The lags of all explanatory variables as well as the branching dummy are used as instruments for endogeneity tests. For each variable, the relevant lags which are strongly correlated with the tested variable, are used . The correlation was checked by means of corresponding regressions. Instrumenting regressions for mortgage fees, which is the key variable of interest as well as for income and mortgage interest rates, which are found to be endogenous, are presented above in Table 5- Table 7. 
Table 9. Results of IV estimations

\begin{tabular}{lcc}
\hline \hline Independent variable & Specification $(2)$ & Specification $(1)$ \\
\hline Interest rate & -.046 & -.049 \\
Mortgage fees & $.022)$ & $(.020)$ \\
Income & -.017 & -0.025 \\
& $(.007)$ & $(.011)$ \\
Population & .875 & .357 \\
User cost & $(.247)$ & $(.123)$ \\
Unemployment rate & 1.953 & 2.285 \\
Construction cost & $(.459)$ & $(.641)$ \\
S\&P 500 & -.152 & -0.325 \\
& $(.096)$ & $(.114)$ \\
& -003 & -.007 \\
& $(.0015)$ & $(.003)$ \\
& & .321 \\
& & $(.124)$ \\
& & .042 \\
Constant & & $(.012)$ \\
& & -.023 \\
& & $(.015)$ \\
\hline
\end{tabular}

Fixed effects 2SLS regression, interest rate and income are the instrumented variables; lags of explanatory variables and the branching dummy are used as instruments. 
Individual researchers, as well as the on-line and printed versions of the CERGE-EI Working Papers (including their dissemination) were supported from the following institutional grants:

- Center of Advanced Political Economy Research [Centrum pro pokročilá politickoekonomická studia], No. LC542, (2005-2009),

- Economic Aspects of EU and EMU Entry [Ekonomické aspekty vstupu do Evropské unie a Evropské měnové unie], No. AVOZ70850503, (2005-2010);

- Economic Impact of European Integration on the Czech Republic [Ekonomické dopady evropské integrace na ČR], No. MSM0021620846, (2005-2011);

Specific research support and/or other grants the researchers/publications benefited from are acknowledged at the beginning of the Paper.

(c) Ashot Tsharakyan, 2008

All rights reserved. No part of this publication may be reproduced, stored in a retrieval system or transmitted in any form or by any means, electronic, mechanical or photocopying, recording, or otherwise without the prior permission of the publisher.

Published by

Charles University in Prague, Center for Economic Research and Graduate Education (CERGE) and

Economics Institute ASCR, v. v. i. (EI)

CERGE-El, Politických vězňů 7, 11121 Prague 1, tel.: +420 224005 153, Czech Republic.

Printed by CERGE-EI, Prague

Subscription: CERGE-EI homepage: http://www.cerge-ei.cz

Editors: Directors of CERGE and EI

Managing editors: Deputy Directors for Research of CERGE and EI

ISSN 1211-3298

ISBN 978-80-7343-157-0 (Univerzita Karlova. Centrum pro ekonomický výzkum a doktorské studium)

ISBN 978-80-7344-146-3 (Národohospodářský ústav AV ČR, v. v. i.) 
CERGE-EI

P.O.BOX 882

Politických vězňů 7

11121 Praha 1

Czech Republic http://www.cerge-ei.cz 